\title{
L'ARBITRATGE REGI A LA CIUTAT DE XÀTIVA EN EL CONTEXT PREVI A LA INTRODUCCIÓ DE LA INSACULACIÓ (1416-1427) ${ }^{1}$
}

\author{
SANDRa Bernabeu BorJa ${ }^{2}$ \\ Universitat de València
}

\begin{abstract}
Resum
Estudi documental que analitza com, a inicis del regnat d'Alfons el Magnànim, la sistemàtica lluita de bàndols entre el patriciat urbà a la ciutat de Xàtiva va determinar una ingerència règia cada vegada més decidida en les eleccions municipals. En aquest sentit, a partir de fonts arxivístiques reials i municipals, la recerca presenta el marc sociopolític existent en dita ciutat i quines foren les primeres petjades de l'arbitratge monàrquic desenvolupat per dit sobirà. En concret, s'exposen els procediments electorals municipals que es succeïren a Xàtiva des de 1416, el fracàs dels quals conduirà a l'atorgament -per primera vegada a la Corona d'Aragó- del privilegi d'insaculació en 1427.
\end{abstract}

\section{Paraules clau}

Intervencionisme monàrquic; Xàtiva; patriciat urbà; segle XV; insaculació.

\begin{abstract}
This article constitutes a documentary research analysing how the endemic struggles among the different patrician factions of the city of Xàtiva, during the early reign of Alfons the Magnanimous, led progressively to a decisive royal interference in the municipal elections. In this regard, this research, based on royal and municipal documentary sources, presents the pre-existent socio-political framework of this city and the first traces left by the royal arbitration carried out by the aforementioned sovereign. More specifically, what is exposed in this paper is the different electoral procedures occurred in Xàtiva from 1416 onwards and whose failure led to the concession -for the first time in the Crown of Aragon- of the privilege of insaculació* in 1427.

*This privilege consisted of a kind of election by sortition -according to the OED's definition: "the casting or drawing of lots; selection, choice, or determination by lot" - through which the municipal authorities were elected.
\end{abstract}

\section{Keywords}

Royal interventionism; Xàtiva; urban patrician; 15th century; insaculació.

1 El present article és una síntesi del punt 1.4. de la tesi doctoral en desenvolupament La ciutat $i$ el rei. Govern, societat $i$ elits valencianes (1416-1479), dirigida per Rafael Narbona Vizcaíno, la qual s'insereix dins del marc del projecte d'investigació del Ministeri de Ciència i Innovació del Govern espanyol (HAR2014-58730-P). Abreviacions emprades: ACA, Arxiu de la Corona d'Aragó; ARV, Arxiu del Regne de València; AMV, Arxiu Municipal de València; LlM, Lletres Missives; MC, Manuals de Consells; RC, Reial Cancelleria.

2 Correo electrónico: sandra.bernabeu@uv.es. 


\begin{abstract}
Resumen
Estudio documental que analiza como, a inicios del reinado de Alfonso el Magnánimo, la sistemática lucha de bandos entre el patriciado urbano de Xàtiva determinó una injerencia regía cada vez más decidida en las elecciones municipales. En este sentido, a partir de fondos archivísticos reales y municipales, la investigación presenta el marco sociopolítico existente en dicha ciudad y cuáles fueron las primeras huellas del arbitraje monárquico desarrollado por dicho soberano. En concreto, se exponen los procedimientos electorales municipales que se sucedieron en Xàtiva desde 1416, e fracaso de los cuales conducirá a la concesión -por primera vez en la Corona de Aragón- del privilegio de insaculación en 1427.
\end{abstract}

\title{
Palabras clave
}

Intervencionismo monàrquico; Xàtiva; patriciado urbano; siglo XV; insaculación.

\section{Introducció}

A inicis del Quatre-cents, la majoria de les ciutats i viles de la Corona d'Aragó estaven immerses en lluites de bàndols que transcendien el marc estamental i es projectaven sobre el conjunt de la societat. Pertot arreu, les profundes rivalitats personals i ambicions polítiques havien anat dividint al llarg de l'últim terç del segle XIV en partits antagònics uns patriciats urbans en pugna pel control dels governs municipals. La renovació anual de les magistratures urbanes en unes dates establertes al llarg de l'any natural i de mecanismes electorals que, tot i la intervenció de l'atzar, conferien una amplia participació ciutadana es van conjugar per a fer de les eleccions municipals un moment propici per a l'esclat de la confrontació social ${ }^{3}$. Aquesta realitat sociopolítica explicaria el per què Martí I va arribar a considerar les bandositats com el pitjor dels mals que podia afectar a un municipi, conceptualització que alhora li permetia justificar la ingerència règia en el govern de les ciutats per tal de sufocar-les:

[...] és escrit e ver que discòrdia entre los de la universitat és verí de la cosa publica de aquella e és més a destrucció de aquella que guerra de stranys e que fams, pestilències e tots altres mals; e per tal, són punidors los torbants

\footnotetext{
3 Al voltant de les lluites de bàndols a la ciutat València al llarg del segle XIV vid. Rafael NARBonA Vizcaíno, Valencia, municipio medieval: poder político y luchas ciudadanas, Ajuntament de València, Valencia, 1995, pp. 129-170; per a Catalunya vid. Flocel SABATÉ CURULL, "Les factions dans la vie urbaine de la Catalogne du XIV e siecle", en Histoire et archéologie des terres catalanes au Moyen Age, 1995, pp. 339-365. Per al regnat de Martí I i durant l'Interregne resulta especialment significatiu el recent monogràfic Maria Teresa Ferrer i Mallol (coord.), Martí l'Humà. El darrer rei de la dinastia de Barcelona (1396-1410). L'interregne i el compromís de Casp, Barcelona, Institut d'Estudis Catalans, Barcelona, 2015. Inclosos en aquell destaquen els articles de Rafael Narbona Vizcaíno, "L'Interregne a València", pp. 767-789; Josep David Garrido i Valls, "Interregne i bandositats a Aragó", pp. 791-814; F. SABAté Curull, "Regnat de Martí I: govern del territori i bàndols", pp. 69-119. Per altra part, en aquest marc de conflictivitat en temps de Martí l'Humà al conjunt dels territoris catalano-aragonesos contrasta amb la relativa pau viscuda a la ciutat de Barcelona, al voltant de dita qüestió vid. M. T. Ferrer i MALlol, "Una època tranquil·la en el govern de Barcelona: el regnat de Martí l'Humà (1396-1410)", Quaderns d'Història, 4 (2001), pp. 165-182.
} 
la pau e repòs publich e és deute e offici del príncep reprèmer, expel·lir, punir e forçar a pau tots faents sedicions, havents dissensions, bregues o bandos e per los quals se torbe $0 \cdot s$ puxa torbar repòs publich... ${ }^{4}$

Expulsar els principals membres de les faccions de la ciutat o de la vila, crear amb caràcter temporal un lloctinent $\mathrm{o}$ virrei amb jurisdicció territorial específicament per lluitar contra les parcialitats o intervindre directament en les eleccions municipals foren algunes de les mesures, que conformaren la política contra els bàndols desenvolupada pel darrer monarca del casal de Barcelona ${ }^{5}$. Aquelles mesures resultaren insuficients, especialment en un regne de València la societat política del qual es trobava netament dividida en dos bàndols, els Vilaragut i els Centelles, que durant l'Interregne assumiren la defensa dels drets dinàstics del comte d'Urgell i de Ferran d'Antequera respectivament. En aquest sentit, en febrer de 1412 la batalla de Codolar esdevindria en l'episodi més sagnant de la lluita de poder entre dues faccions que, més enllà del suport armat atorgat a un o a un altre candidat a la corona, es disputaven des de feia dècades el control del govern municipal de la ciutat de València i, possiblement, de la resta de ciutats i principals viles del regne. En aquest context, després de la sentència de Casp, l'ascens al tron de la dinastia Trastàmara a la corona va significar per als membres del bàndol dels Centelles una oportunitat per a excloure de les institucions de govern als seus tradicionals rivals, mentre que els membres de la derrotada facció dels Vilaragut intentarien resistir en aquelles institucions $o$ almenys tornar-se a integrar ràpidament ${ }^{6}$.

Significativament il·lustratiu resulta el cas del govern municipal de la ciutat de València, el qual durant l'Interregne va romandre sota la influència dels Vilaragut, passant a mans exclusivament dels Centelles a partir de les eleccions dels jurats i del consell de 1412. És a dir, tot i que a la ciutat de València el 17 de març de 1412 es va posar en vigència

\footnotetext{
4 Mateu Rodrigo Lizondo (Ed.), Col-lecció documental de la Cancelleria de la Corona d'Aragó. Textos en llengua catalana (1291-1420), PUV, València, 2013, vol. II, pp. 968-969, doc. 904.

5 Al voltant de la creació de la figura del lloctinent o virrei per a una determinada demarcació territorial vid. F. Sabaté Curull, "Regnat de Martí I: govern del territori... p. 106-114; per altra part, R. Narbona Vizcaíno ha documentat com Martí l'Humà en 1401 i 1404 va intervindre en l'elecció dels jurats de la ciutat de València mitjançant la introducció d'una nòmina de candidats a la juraderia, el que segons dit autor és pot considerar el precedent immediat de la ceda reial establerta per Alfons el Magnànim. Així mateix també ha documentat com en 1406 el monarca va procedir a realitzar una designació directa tant de l'executiu de govern valencià com dels consellers d'aquella anualitat, vid. R. NARBONA VizCAíno, "L'Interregne a València...p. 781. Designacions de la juraderia per part de la Corona s'havien produït en temps de Pere el Cerimoniós de forma puntual, en concret en 1348 i 1349 vid. M. Rodrigo Lizondo (Ed.), Diplomatari de la unió del regne de València (1347-1349), PUV, València 2013, p. 356, doc 172; p. 334, doc 165. De fet, el propi Cerimoniós va intentar introduir per primera vegada una ceda reial en 1357 vid. Ignacio ViLlalongA Vilalba, Los Jurados y el Consejo. Regimen Municipal foral valenciano, Tesis doctoral, 1916, ed. Banco de Valencia, Valencia, 1995, pp. 23-24 (doc. VII, pp. 85-86); també citat per Ernest Belenguer Cebrià, Valencia en la crisis del siglo XV, Edicions 62, Barcelona, 1976, p. 35.

${ }^{6}$ Aquest dinàmica d'excloure del govern als antics militants del bàndol dels Vilaragut es projectaria en la designació d'oficials reials per part de la monarquia, situació que fou protestada en les corts de 1417-1418 vid. Carlos López Rodríguez, Noblesa y poder político en el reino de Valencia, PUV, València, 2005, p. 251.
} 
una reforma del sistema electoral, proveïda per Martí en les corts de 1401-1407, que incrementava la intervenció de l'atzar en la renovació dels principals càrrecs públics ${ }^{7}$, aquell va romandre mediatitzat pel grup de poder vencedor militarment a Codolar, i diplomàticament a Casp. Ara bé, com ha mostrat A. Rubio Vela, al llarg d'aquests anys polítics les eleccions de la màxima magistratura urbana van estar envoltades de greus tensions sociopolítiques davant la inquietud dels centellistes a què els seus adversaris es feren en el poder municipal, aprofitant les simpaties populars que gaudia l'urgellisme a la capital del regne abans i immediatament després de la insurrecció de Balaguer. Situació que segons l'executiu de govern valencià era plausible perquè els oficials reials no proveïen en contundència contra els partidaris del comte d'Urgell. Aquesta acusació es veu referendada en la postura adoptada per Joan Mercader, batle general, i altres oficials, els quals -sempre i quan no afectaren als seus interessos particulars ${ }^{8}$ - eren obertament defensors de què la monarquia desenvolupara una política reconciliadora entre els dos bàndols i que els derrotats no foren exclosos en les institucions del govern municipal ${ }^{9}$. En aquest context, com recull documentalment A. Rubio, malgrat les temors inicials les eleccions dels magistrats valencians en 1413 conformaren un executiu de govern de persones afectes la monarquia, tal i com el sobirà hauria ordenat prèviament. El mateix succeiria en les eleccions dels regidors de la ciutat un any després, tot i que en aquell cas, en previsió de possibles altercats, el governador junt al seu lloctinent i el justícia criminal de la ciutat van exhibir des de dies abans de l'elecció la seua capacitat coercitiva pels carrers de la capital del regne ${ }^{10}$. Ara bé, tot i el recel dels jurats contra les possibles conspiracions i accions organitzades per part dels Vilaragut, segons es desprèn d'una lletra del batle general, Joan Mercader, el que provocava tensió a la ciutat era les ànsies de revenja de Bernat Centelles i Pere Maça. Tots dos, caps de bàndol dels Centelles, estarien més compromesos que mai contra els pro-urgellites de la ciutat i del regne després d'haver capitanejat l'exèrcit reial en el setge contra Balaguer feia poc més de sis mesos. Almenys això és el que s'intueix de la lletra del 26 de maig, en la que el batle general notificava a Ferran I com, malgrat l'agitació social viscuda, les eleccions s'havien desenvolupat de forma pacífica, gràcies al «bon esforç del governador, e altres officials vostres, e per bon seny de mossèn Bernat Çentelles e don Pere Maça, qui són estats molt obedients a vostres officials, majorment aprés que aguen rehebudes

\footnotetext{
R. NARBONA, Valencia, municipio medieval...pp. 46-47.

8 La defensa del discurs conciliador de Joan Mercader es pot matisar, en tant que es documenta com en 1416 aquell intercedeix en favor del nomenament d'Antoni Martorell com a batle d'Alzira, argumentant la fidelitat d'aquell en contraposició a Miquel Vendrell, qui hauria estat prourgellista. vid. ACA, RC, Cartes Reials, Alfonso IV [V], fol. 249r (9 d'agost de 1416).

9 Agustín Rubio Vela, "Urgellistas valencianos. Sobre la oposición a Fernando I de Trastámara", Anuario de Estudios Medievales, 33 (2003), pp. 217 i 238.

10 Ibíd. En 1413 els magistrats de la ciutat, de clar perfil centellista, foren: pels ciutadans Jaume Celma, Bernat Joan, Joan Valleriola i Jaume Vich; mentre que els cavallers foren Manfré Romaní, alies Escrivà, i Jaume Serra. El magistrat Bernat Joan, seria individu diferent al jurat de nom homònim de 1410 i 1415 , de fet a aquest Joan seria jurat també en 1416, un any després de que ho forà el seu homònim urgellista.
} 
vostres letres ${ }^{11}$. Aquestes paraules de Joan Mercader revelen com el monarca hauria tingut que intercedir per a dissuadir als líders del grup de poder que gaudia del control de la ciutat i que estaria decidit a emprendre mesures contra possibles simpatitzants de la causa del comte d'Urgell.

Ara bé, què va ocórrer en les eleccions de la juraderia de 1415, en les quals van sorgir elegits com a magistrats pels ciutadans Bernat Joan i Ramon Gostantí, qui presentaven un passat urgellita? ${ }^{12}$ Doncs, que Ferran I aprofitant la seua presència en la ciutat de València va executar la directriu política de reconciliació demanada pels seus oficials reials del regne, el que va permetre l'accés al govern de la ciutat d'antics valedors dels Vilaragut ${ }^{13}$. D'aquesta manera, les principals aprensions dels centellistes durant els darrers dos anys s'acompliren, afavorides per la pròpia política monàrquica, el que va provocar una gran contrarietat en el si d'aquest sector de l'elit dirigent valenciana. Una contrarietat que explicaria les tensions sociopolítiques que envoltarien les eleccions de la juraderia i del consell de 1416. Doncs, en aquella conjuntura, aprofitant el recent accés al tron d'Alfons el Magnànim, la facció dels Centelles, o almenys un sector d'aquella, intentaria emprant estratègies habituals controlar novament en exclusiva el govern municipal de la capital, però també el de la segona ciutat del regne, Xàtiva. El primer testimoni documental al respecte d'aquestes tensions vers les eleccions de 1416, es va produir el 24 de maig, tretze dies abans de la vespra de Pentecosta ${ }^{14}$. En aquella data, els magistrats de la ciutat de València alarmats escrivien el següent als seus missatgers en la cort reial:

[...] som estats informats que mossén Guido de Veintimilla ve ací a la dita ciutat ab certes provisions del senyor rey dirigides als governador, batle general, justícies e jurats de la dita ciutat, per les quals los certifica e mana que certes

\footnotetext{
11 Margarita Tintó SAla, Cartas del Baile General de Valencia, Joan Merceder, al rey Fernando de Antequera, CSIC, Valencia, 1979, p. 212, doc. 44. L'executiu de govern elegit en 1414 estava constituït pels ciutadans Gabriel Palomar, Pere Passadores, Ramon Salars i Joan Suau mentre que pels cavaller Bernat de Montsoriu i Gispert Valleriola.

12 El perfil pro-urgellista de Bernat Joan i Ramon Gostant $i$ es definit en tant que aquells van desenvolupar la juraderia de la ciutat de València en 1410, quan el govern de la ciutat estava sota la influència dels Vilaragut. Al voltant del desenvolupament de càrrecs públics de Ramon Gostantí vid. R. NARBONA VizCAíNO, "Cultura política y comunidad urbana: Valencia, siglos XIV-XV", Edad Media, Revista de Historia, 14 (2013), p. 195. En el cas de Bernat Joan és directament identificat entre els valedors dels Vilaragut durant l'Interregne (vid. R. Narbona, “L'Interregne a València...p. 769), l'extens nombre de càrrecs desenvolupats fa impossible descriure'ls ací.

13 La presència de Ferran I a la ciutat de València està documentada al llarg de vuit mesos compresos entre el 22 de desembre de 1414 i el 22 d'agost de 1415, al respecte vid. Santiago GonzÁlez SÁnchez, Itinerario de don Fernando, regente de Castilla y rey de Aragón (1407-1416), CSIC, 68 (2013), pp. 200; $263-266$. Al voltant de la concepció conciliadora dels oficials reials i especialment de Joan Mercader vid. A. RuBIO Vela, "Urgellistas valencianos... p. 191-261.

14 La vespra de Pentecosta o quinquagèsima era la data en la que a la ciutat de València i a la resta de ciutats i viles del regne es celebraven les eleccions els jurats. Tot i ser una data mòbil del calendari cristià es pot situar entre finals del mes de maig i inicis de juny.
} 
persones axí dels cavallers com dels ciutadans nomenats en les dites letres meten en la sort de la elecció de jurats, manat als dits governador e batle e $a$ altres oficials reyals que $n$ esforcen ab tots aquelles remeys que puxen, de què nosaltres som molt meravellats si les dites coses són veres com són axí exides de la cort del dit senyor e obtingudes, que vosaltres senyors qui sots aquí per la dita ciutat no hajats haud sentiment per què com les dites coses sien malvades, e en total destrucció e extermini de les dites ciutats [València i Xàtiva] e regne de València, e molt desaforades e contra libertats de les dites ciutats e regne... ${ }^{15}$

Els qualificatius emprats, «total destrucció e extermini de les ciutats e del regne», expressen com era percebuda aleshores una possible intervenció del monarca en favor de certes persones en les eleccions de l'executiu de govern de les dues ciutats més importants del regne. Però, què importunava als regidors de la ciutat de València, el procediment en què el monarca pretenia intercedir en l'elecció o el perfil polític dels candidats reials? Com hem dit anteriorment, R. Narbona ja ha assenyalat com en 1401 i 1404 l'elecció de l'alta magistratura urbana a la ciutat de València es va efectuar a través d'una nòmina de candidats prèvia, mediatitzada en aquell cas pels consellers de Martí l'Humà ${ }^{16}$. És a dir, el procediment no era una novetat, doncs feia aproximadament poc més d'una dècada que havia estat emprat pel darrer rei del casal de Barcelona. Mentre que, per altra part, la relació dels nominats presumiblement devia incloure en exclusiva a membres de la facció centellista, segons es desprèn de la voluntat del nou monarca coneguda a partir d'una lletra de Vidal de Blanes, governador del regne. Doncs, aquest oficial reial el 19 de juny -és a dir dies després de les eleccions-informava al propi monarca com, seguint els seus manaments, hauria ordenat als jurats vells de la ciutat que en l'elecció dels nous magistrats «per res no elegissen jurats ni consellers, nengú que no hagués hauda bona afecció e bon voler al senyor rey, pare vostre de memòria gloriosa, ni elegissin nengú que fos estat afeccionat a don Jaume d'Urgell ni a Bellera.... $\rangle^{17}$. És a dir, el governador del regne -prèvia ordre règia- hauria manat als regidors de la capital, entre els quals almenys hi hauria dos membres representants del sector dels Vilaragut (Bernat Joan i Ramon Gostantí), que no nominaren com a candidats a la màxima magistratura urbana a persones sospitoses d'haver abraçat la causa urgellista. L'excepcionalitat del caràcter explícit i directe del llenguatge emprat per Vidal de Blanes - qui es defensava davant del monarca perquè l'havia acusat de no haver aplicat les provisions que devia- permet establir amb total certesa que la conflictivitat sociopolítica que va condicionar les eleccions municipals en 1416 no era tant la possible aplicació de la ceda reial com els interessos particulars en joc. Uns interessos que en aquell cas implicaven obtindre el control absolut de les dues ciutats més importants del regne en el cas dels Centelles, mentre que els Vilaragut es jugaven

AMV, LIM, $\mathrm{g}^{3}-13$, fol.109v-110r (24 de maig de 1416).

6 Vid. nota 5.

${ }^{17}$ ACA, RC, Cartes Reials, Alfonso IV [V], fol. 161r (19 de juny de 1416). 
quedar o no exclosos de les institucions de govern de dites ciutats. És a dir, la lluita de poder entre dues tradicionals faccions en què es dividia el patriciat urbà valencià abans de l'Interregne continuava essent la mateixa que en 1416 es disputava el control del govern municipal de la ciutat de València i la de Xàtiva.

Amb tot, enllaçant amb aquestes dinàmiques prèvies, el present estudi té l'objectiu de contribuir a comprendre amb major perspectiva històrica la conjuntura inicial que va precipitar la intervenció sistemàtica i decidida d'Alfons el Magnànim en la conformació del govern de la ciutat de Xàtiva, immediatament després del seu accés al tron. Doncs, en el marc de la historiografia sociopolítica peninsular dedicada a l'estudi del règim municipal la ciutat de Xàtiva és singularment coneguda com la primera urbs de la Corona d'Aragó en rebre el privilegi d'insaculació en temps dels Trastàmara. Ara bé, més enllà d'aquesta referència, poc s'ha profunditzat en el context específic que va conduir al Magnànim i als seus consellers reials a posar en pràctica en 1427 un sistema d'elecció municipal, que amb el pas de les dècades es difondria paulatinament pertot arreu de la geografia catalano-aragonesa. No obstant això, si que s'ha subratllat encertament en nombroses recerques com la insaculació fou l'instrument electoral que va permetre a la monarquia arbitrar els conflictes interns que assolaven unes elits dirigents locals dividides $i$ en continua lluita pel poder governamenta ${ }^{18}$. Per altra part, tot $i$ que es reconeix el caràcter d'intercessió de la insaculació com a element relativament pacificador de les bandositats locals ${ }^{19}$, l'acció interventora de la Corona en el govern de les ciutats s'ha interpretat com l'expressió més visible d'un nou model polític, conceptualitzat en termes d'autoritarisme regi ${ }^{20}$. Ara bé, aquesta rellevància de la insaculació com a símbol de les noves directrius governamentals dels Trastàmara no ha suscitat fins el moment un intent de profunditzar en els orígens i les controvèrsies del seu primer establiment a la ciutat de Xàtiva. Per tant, en aquest sentit, aquest buit historiogràfic justifica el present article, el qual davant la manca de conservació de documentació municipal de dita ciutat relativa aquest període s'aborda especialment a partir dels registres de la cancelleria reial de la Corona d'Aragó ${ }^{21}$. Així mateix, aquesta documentació reial s'ha confrontat amb

\footnotetext{
18 En concret, s'ha posat en relleu com l'aparent èxit de la insaculació era avançar el moment de tensió social intrínsec a la nominació de candidats per als càrrecs municipals a dates llunyanes del propi dia de l'elecció, on el malestar social dels individus exclosos havia disminuït i, per tant, dissuadit d'iniciar nous conflictes.

19 Aparent èxit perquè com s'ha demostrat les bandositats i les lluites pel poder entre famílies enfrontades en el municipi van continuar tot i la vigència del sistema insaculatori.

20 Per citar alguns treballs de síntesi Maria BARCeló Crespí (Coord.), El règim municipal a la Corona d'Aragó, Estudis Baleàrics, Institut d'Estudis Baleàrics, 31 (1988); David Bernabé Gil, "Els procediments de control reial sobre els municipis valencians segles XVI i XVII", Recerques, 38 (1999) pp. 27-46; Amparo FeLIPo ORTS, Autoritarismo monárquico y reacción municipal. La oligarquía urbana de Valencia desde Fernando el Católico a las Germanías, PUV, Valencia, 2004; Josep Maria Torras i Ribe, "El procedimiento insaculatorio en los municipios de la Corona de Aragón, entre la renovación institucional y el sometimiento a la monarquía (1427-1714)”, en Jerónimo Zurita: su época y su escuela, 1986, pp. 341-352.

21 A l'Arxiu Municipal de Xàtiva s'han conservat les actes municipals de 1379-1380 -vid. Alfred BoludA Perucho, Els Manuals de Consells medievals de Xàtiva (1376-1380), Diputació Valenciana, València, 1999-i un manuscrit relatiu a les eleccions dels Jurat i del Consell de 1405-1406. A partir d'aquesta documentació Emilia Mollà va realitzar una aproximació a l'estructura de govern municipal xativí, el qual reprodueix a
} 
les lletres missives de la ciutat de València, conservades a l'Arxiu municipal de dita ciutat. Doncs, el context de tensions sociopolítiques generals en el regne de València en 1416 junt al recolzament ofert pel govern municipal de la capital al govern xativí en un primer moment front a l'arbitratge monàrquic expliquen com la correspondència de la ciutat de València esdevé en un testimoni documental clau per al dit estudi.

\section{Les eleccions dels jurats i del consell de Xàtiva en $\mathbf{1 4 1 6}$}

Respecte a la ciutat de Xàtiva es desconeixen les seues dinàmiques polítiques pròpies durant el regnat de Ferran I, el que dificulta una aproximació prèvia al context anterior a les eleccions de 1416. Tot i que sí es coneix com la dita ciutat fou un dels principals escenaris de les parcialitats durant l'Interregne, per exemple s'ha destacat com allí es refugiaren els Centelles en novembre de 1409, una data en què s'enregistra una batalla que enfronta als bàndols amb ús fins i tot d'artilleria ${ }^{22}$. Així mateix, com ja ha anunciat també la historiografia, un dels principals activistes de les bandositats del regne d'inicis del Quatre-cents fou el noble xativí Pere Maça de Liçana, senyor de Moixent ${ }^{23}$. Aquest, com molts altres nobles i cavallers del regne, primer havia liderat la causa dels Vilaragut però en esclatar el conflicte dinàstic va passar a ser un dels caps de bàndol dels Centelles i, per tant, defensor a ultrança dels drets a la corona de Ferran d'Antequera ${ }^{24}$. En aquest sentit, la presència de Pere Maça a Xàtiva no deixava indiferent a ningú, especialment perquè s'ha de considerar que a les altures de maig de 1416, el govern municipal de dita ciutat estava sota el control exclusiu de la facció valedora dels Vilaragut. En aquest context, la facció exclosa del govern a Xàtiva personalitzada a través de Pere Maça estava disposada a recuperar el poder governamental confiant o bé instrumentalitzant el suport de la monarquia regnant. De fet, les explicacions donades pel dit noble, en un consell general de la ciutat de Xàtiva celebrat posteriorment aquell mateix any, reconeixia com hauria anat a dita ciutat el dia de les eleccions dels jurats per servei del rei i per vetllar que el nou govern municipal estiguera conformat de forma equitativa entre «sos

xicoteta escala el model de la ciutat de València vid. Emilia Mollà RiBES, "El govern municipal de la ciutat de Xàtiva en la baixa edat mitjana (segles XIV i XV)", Xàtiva, Fira d'agost, 1983.

22 R. Narbona Vizcaino, "L'Interregne a València"... p.783.

23 Per Maça en 1414 era conseller i majordom de Ferran vid. MARtí De Riquer, Vida i aventures de don Pero Maça, Edicions dels Quaderns Crema, Barcelona, 1984. Al voltant de Pere Maça vid. també José Hinojosa Montalvo, Crònica de Pere Maça, PUV, València, 1979.

24 En 1410 Pere Maça amenaçava contínuament d'entrar la ciutat de Xàtiva amb armes amb la finalitat d'expulsar els Centelles. No obstant això, en el 31 desembre de 1411, Pere Maça entrava junt a Francesc Soler, Lluís Pertusa, i Juan Ferrandez de Heredia, declarats centellistes a Alzira després d'haver-se aliat amb els alzirenys Pere Lloret i Antoni Martorell. Així doncs, seria de presumir que en el mes de juliol anterior Pere Maça hauria format part dels nobles, cavallers i particulars de Xàtiva que prengueren el poder de la ciutat i negaren l'entrada a Arnau Guillem de Bellera, governador del regne. Cfr. Pascual Beltrán VentuRA, "Játiva y la elección de sucesor de don Martín el Humano", al III Congreso Historia de la Corona de Aragón, vol. 1,València 1923, pp. 439-485; R. NARBona Vizcaino, "L'Interregne a València...pp. 770-773. 
amichs et los altres, qui solien esser llurs contraris $\rangle^{25}$. En un ambient de tal naturalesa, com veurem a continuació, dos anys després de què el sobirà tinguera que intercedir per a què Pere Maça no provocara disturbis a la ciutat de València amb motiu de les eleccions de la juraderia de 1414, novament aquell era el principal assenyalat com a factor de conflictivitat en les eleccions de la segona ciutat del regne.

\subsection{La causa immediata de la tensió política: la ofensiva del bàndol dels Centelles per recuperar el control de Xàtiva}

Ara bé, centrant-nos ja en els esdeveniments succeïts dies abans de l'elecció, cal remarcar com el començament de les tensions es va produir, com hem dit anteriorment, a partir de què els jurats de la ciutat de València notificaren als seus missatgers en la cort reial com Guido de Veintimilla duia una cèdula del monarca, que contenia el nom d'una relació de persones que devien ser incloses en les eleccions dels jurats de la ciutat de València i de la ciutat de Xàtiva. En aquella mateixa lletra, datada el 24 de maig de 1416, els magistrats de la capital informaven a més a més que certs nobles, cavallers i gentilshomes amb lletres de creença de Pere Maça i de Joan Ferrández de Heredia havien estat cridats a les armes «per metre en revolta e brogit en la jornada de la elecció de la juraderia, axí de la ciutat de València com la ciutat de Xàtiva». Davant aquesta greu situació, els edils de València ordenaren als dits missatgers que primer confirmaren la notícia $\mathrm{i}$ en cas que fora certa feren revocar aquella provisió reial, suplicant al rei «que tals o semblants provisions no vulla d'aquí avant atorgar a alcuna persona com sien destruiments del ben publich e incentives a escàndels e perills irreparables $»^{26}$. Gairebé al mateix temps, l'executiu de govern de la capital advertia al monarca que els regidors de Xàtiva s'estaven mobilitzant amb amics i gent d'armes davant les informacions que arribaven al voltant de què Pere Maça havia convocat a homes per a anar a dita ciutat el dia de l'elecció dels nous magistrats. Front aquests fets, el govern municipal valencià li recriminava al Magnànim com ells havien tingut que notificar els fets al governador -que justament en aquella conjuntura es trobava intercedint en les eleccions municipals de la vila d'Alzira ${ }^{27}$ - per a què es fera càrrec de dit assumpte, tot i que era a ell com a monarca a qui pertocava vetllar pel «pacífich estament de vostres pobles e menar que tals coses cessen $»^{28}$. En aquesta mateixa direcció, els magistrats de València ordenaven als seus missatgers en la cort reial que junt al suport d'Olfo de Pròixida, del Mestre de Montesa, d'Aimeric Centelles, de Pere Pardo i d'altres homes de confiança del govern

\footnotetext{
25 Aquestes explicacions de Pere Maça es recullen a partir d'una lletra enviada pels jurats de Xàtiva Francesc Bosch i Berenguer March al monarca en el que descriuen com es desenvolupa dit consell vid. ACA, RC, Cartes Reials, Alfonso IV [V], fol. 200r (4 de juliol de 1416).

26 AMV, LlM, g3-13, fol.109v-110r (24 de maig de 1416).

27 El govern municipal envià una lletra de creença al governador, al batle general i a Guillem Saera, en favor dels missatgers enviats a Xàtiva Guillem Solanes i Tomàs Coblliure. Serien aquests els que explicarien als tres consellers reials l'increment de les tensions a la ciutat de Xàtiva vid. AMV, LM, g3-13, fol. 114v (4 de juny de 1416).
}

28 AMV, LlM, g⿳3 -13 , fol. 113r-v (4 de juny de 1416). 
de la ciutat en la cort reial pregaren al monarca que «proveesqua degudament e presta, com açò sia cosa en què va grantment a sa senyoria e al benavenir de aquest regne» ${ }^{29}$. Davant l'escalada de tensions, el rei hauria manat a l'advocat fiscal en Xàtiva, Pere de Fachs, i al cavaller Joan Fabra, que en nom seu es feren càrrec de les eleccions dels jurats de Xàtiva. Precisament, seria una lletra d'aquests dos oficials reials al monarca, datada el 13 de juny i signada de forma autògrafa per aquests dos a més de pel governador i pel batle general, a partir de la qual coneixem gran part del procediment electoral desenvolupat en dita ciutat per a renovar les seues magistratures municipals. En dita lletra, els dits oficials notificaven al Magnànim que la situació en dita ciutat quan arribaren era tan greu i conflictiva que podria haver afectat al conjunt del regne. D'aquesta manera, els oficials reials justificaven que la seua intromissió en les eleccions havia esdevingut important, qualificant-la fins i tot de «rigorosa» però «lícita» i necessària ${ }^{30}$. Així mateix, informaven que havien tingut que comptar amb el consell del governador del regne i de Joan Mercader, batle general, que per motius semblants havien acabat d'intercedir en les eleccions de la juraderia de la vila d'Alzira, com veurem més endavant. En aquest sentit, dies després el propi Joan Mercader reconeixia al secretari reial Paulo Nicolás que, acabats els seus afers en la dita vila, van emprendre el camí a Xàtiva conscients que «molta gent de aquest regne ab armes, en prou desonesta manera, anaven a Xàtiva per escandalitçar la elecció en gran perill de la dita ciutat e llur...». Ara bé, per a no interferir en el poder atribuït pel Magnànim a Joan Fabra i Pere de Fachs, tant el governador com el batle general van decidir aturar-se prop d'aquella ciutat i esperar que aquells sol·licitaren la seua presència tal i com va succeir ${ }^{31}$.

Seria abans de la intermediació d'aquests dos alts oficials reials, quan es produiria l'intent de Pere de Fachs i Joan Fabra d'aplicar la ceda reial en les eleccions de l'executiu de govern xativí, tot i que no es mencionat en la seua lletra al monarca. En aquest punt, seria on les mostres de preocupació i nerviosisme dels jurats de la ciutat de València serien extraordinàries, fins al punt de pregar a Guillem Solanes i a misser Tomàs de Coblliure, missatgers del govern valencià a Xàtiva, que «ab correus volants de ora en hora», els anaren informant dels esdeveniments, especialment davant la possibilitat que homes armats es dirigiren cap a la capital del regne ${ }^{32}$. Aquest patiment encara es va intensificar més davant les notícies de què Joan Fabra i Pere de Fachs havien iniciat alguns procediments contra l'executiu de govern xativí i el seu escrivà municipal, i inclòs arribaren rumors del seu arrest. Davant aquesta controvertida situació, el govern de la capital pregava al de Xàtiva que celebraren eleccions d'acord amb els furs i privilegis del regne, indicant que si se ho impedien -en tant que no pensaven que aquella fora la intenció del rei- feren les degudes protestes. Al

29 AMV, LlM, $\mathrm{g}^{3}-13$, fol. 113r (4 de juny de 1416). Altra còpia d'aquesta lletra es conserva en els registres de cancelleria a ACA, RC, Cartes reials, Alfonso IV [V], fol. 132r.

30 ACA, RC, Cartes Reials, Alfonso IV [V], fol. 148r a-b-c (13 de juny 1416). Tot el procediment seguit en aquelles eleccions es recull en aquest document.

31 ACA, RC, Cartes Reials, Alfonso IV [V], fol. 156r (17 de juny de 1416).

${ }^{32}$ AMV, LIM, g⿳⺈冂䒑十, fol.114r (4 de juny de 1416). 
mateix temps, els magistrats de la ciutat de València enviaven una lletra adreçada als esmentats Pere de Fachs i Joan Fabra, advertint-los que en cas que les informacions que havien rebut foren verídiques deslliuraren als jurats i a l'escrivà i cessaren els seus procediments contra aquells, doncs del contrari estaven actuant contra furs i privilegis $i$ bons usos de la ciutat $i$ del regne, els quals el monarca feia poc havia jurat respectar ${ }^{33}$. Cal assenyalar com en la lletra del dia 13 de juny de Fabra i Fachs al monarca tampoc mencionen les disputes que tingueren amb els jurats xativins i el suposat empresonament, tot i que cert que en dita missiva adverteixen al rei que no li van a detallar tots els esdeveniments, remarcant-li únicament que tots aquells foren fets per necessitat davant una situació difícil de resoldre ${ }^{34}$.

Uns esdeveniments que en tot cas il·lustren com fins a l'arribada de Vidal de Blanes, governador general, i de Joan Mercader, batle general, els dos comissaris del rei a Xàtiva no s'havien fet amb el control de la situació, sinó que més bé la seua gestió hauria incrementat considerablement el malestar en la ciutat. És a dir, únicament la presència personal en Xàtiva del governador i del batle general hauria aconseguit obrir un espai de negociació entre les faccions fins arribar a un acord mitjançant l'arbitració dels oficials reials. Així mateix, la necessària acció conjunta dels quatre oficials regis i l'advertència posterior al monarca de què havien procedit a gestionar la situació de la millor manera que havien pogut després d'unes negociacions amb l'elit dirigent complicades mostren l'esforç de l'administració reial per aconseguir que la renovació del govern de Xàtiva es desenvolupara «pacíficament e ab gran egualtat, unanimitat e concòrdia, juxta los furs e privilegis e bons usos de la ciutat dessús dita, e segons per vos senyor era estat manat.... $\rangle^{35}$. Tot seguit, es va notificar al monarca com havien procedit per a realitzar l'elecció de cada un dels càrrecs del nou govern municipal.

\subsection{La primera elecció del govern municipal: 6 de juny de 1416}

Així doncs, al respecte de la renovació dels quatre membres que constituïen l'executiu de govern xativí únicament li notificaven al Magnànim com aquella s'havia realitzat amb l'acord dels jurats i els consellers vells. Una avinença que va propiciar que foren elegits magistrats els ciutadans Francesc Bosch, Berenguer March, Lluís Ferrer i Pere de Gallach, que teòricament representaven als dos bàndols existents en la ciutat, com s'al·ludeix a través del concepte «egualtat», anteriorment citat. Al mateix temps, informaven com s'havia fet elecció del jutge de les imposicions i dels tres comptadors corresponents mitjançant acord unànime de tothom ${ }^{36}$, situació que no

\footnotetext{
33 AMV, LIM, g⿳⺈-13, fol. 115v (5 de juny de 1416).

34 ACA, RC, Cartes Reials, Alfonso IV [V], fol. 148r a-b-c (13 de juny 1416): «certificam senyor tots quatre ensemps, la vostra magestat real que aprés molts contrarietats, actes, debats e contencions, los quals escriure per menut seria molt prolix, e a la vostra senyoria hoir molt tediós..».

35 Íbid.

36 Ibíd. El ciutadà Domingo del Castellar fou elegit com jutge de les imposicions, mentre que els també ciutadans Francesc Foera, Lluís Millà i Joan Amat foren elegits comptadors.
} 
havia estat possible en el cas de l'elecció dels catorze consellers que constituïen el consell particular de la ciutat de Xàtiva. Al respecte d'aquesta elecció de consellers, els oficials reials asseguraven que la primera intenció era realitzar-la seguint el mateix procediment que en l'elecció dels quatre regidors, és a dir mitjançant un consens entre els jurats i consellers de l'anualitat anterior. Ara bé, davant la impossibilitat d'arribar a una concòrdia, es va prendre la decisió de designar indirectament als consellers sota l'assessorament de persones «comunes e indiferents de la dita ciutat» ${ }^{37}$. És a dir, els oficials reials van realitzar una cooptació de consellers amb l'assessorament -interessat o no- d'individus no involucrats en la lluita de bàndols, o almenys no identificats públicament com a membres d'alguna de les faccions. Una designació que, per altra part, segons confessaven els oficials reials va ser realitzada «ab la maior egualtat que havem poscut ymaginar e trobar». I de fet, així es constata, tenint en compte que es va recercar una solució que garantia una representació equitativa tant entre persones immerses i no immerses en bandositats com entre els membres d'ambdues faccions. Tot plegat, el seguiment d'aquesta directriu va exigir el desenvolupament d'un procediment singular, que va ser descrit minuciosament al monarca per part de Pere de Fachs i Joan Fabra en aquella mateixa lletra del 13 de juny.

Així doncs, segons aquells, de les dues places de consellers generosos una, d'acord amb la legislació vigent, devia recaure en el jurat generós que deixava la magistratura. Per tant, seguint aquesta pauta un dels càrrecs de consellers generosos seria desenvolupat per Lluís Ponç de Fenollet, qui va ser reconegut per tothom com a persona indiferent a les parcialitats. Pel que fa a l'altra plaça reservada als generosos, en tant que els representants d'ambdós bàndols van ser incapaços de reconèixer un altre individu de dita condició que no participara en elles, es va procedir a fer sorteig de redolins únicament entre dos individus, cada un representant d'una de les dues faccions. En aquest sentit, Pere de Castellar va ser nominat com a candidat per part d'un dels bàndols, mentre que per part de l'altre va ser nominat candidat $-\mathrm{i}$, finalment, elet conseller pels generosos- Miquel $\mathrm{Sanç}^{38}$. El fet que foren nominats aquests com a representats d'ambdues faccions per al càrrec de conseller de cavallers potser indicatiu de què aquells eren els caps de bàndol $\mathrm{o}$ individus rellevants dins de cada una de les faccions en què es dividia la societat política de la ciutat de Xàtiva. Aquesta possibilitat justifica el per què en endavant emprarem amb una finalitat purament conceptual el cognom Castellar per referir-nos a una facció i el Sanç per a al'ludir a l'altra.

Pel que fa a les resta de les dotze places de consellers ciutadans, aquestes es van distribuir la meitat entre els individus que participaven en les bandositats i l'altra meitat entre individus que eren aliens aquelles. Així mateix, les sis places corresponents als individus indiferents van ser repartides quatre entre els ciutadans i les dues restants entre ciutadans de la mà menor. Mentre que les sis places reservades als individus relacionats amb les parcialitats foren distribuïdes entre tres partidaris dels Castellar

ACA, RC, Cartes Reials, Alfonso IV [V], fol. 148r a-b-c (13 de juny 1416).

38 Ibid. 
i les altres tres entre els dels Sanç. Ara bé, en tant que els tres ciutadans jurats vells, segons la normativa electoral vigent, devien formar part del consell i coincidia que eren de la mateixa parcialitat, aquests foren nomenats directament consellers per aquella. És a dir, les tres places que corresponia a la facció que l'any anterior havia controlat el govern municipal de la ciutat serien desenvolupades pels tres jurats ciutadans que deixaven la magistratura -tot i que l'estat actual de la investigació no permet identificar encara a quin dels dos bàndols es corresponia. Per la seua part, l'elecció de les tres places de l'altra parcialitat, la qual havia estat marginada del govern municipal l'any anterior, es va realitzar a partir d'un sorteig de redolins entre dotze candidats de la facció. Doncs, la lògica esgrimida pels oficials reials era que si els tres consellers de l'altre bàndol l'any precedent havien estat extrets entre els dotze candidats a jurats, de forma semblant devien ser elegits els tres consellers de l'anomenada facció «foragitada del regiment». Tot plegat, descrites al detall les eleccions dels jurats i del consell, Pere de Fachs i Joan Fabra pregaren en dita lletra al monarca que no modificara en res l'elecció feta a Xàtiva fins almenys quan aquell es trobara personalment al regne. Doncs, com els oficials reials reconeixien cap de les dues parcialitats havia quedat contenta $i$, en conseqüència, per tant preveien $i$ advertien al monarca com tant els membres del bàndol dels Castellar com els dels Sanç li suplicaren modificar dita elecció ${ }^{39}$.

Fet $\mathrm{i}$ fet, de tota aquesta descripció del procediment concernent a les eleccions dels jurats i del consell de Xàtiva de $1416 \mathrm{cal}$ destacar el seu caràcter extraordinàriament improvisat. Doncs, com s'observa l'advocat fiscal Pere de Fachs, Joan Fabra, Vidal de Blanes, governador del regne, i Joan Mercader, batle general, van procedir no amb fórmules de representativitat electorals planificades -representació parroquialsinó que van tindre que recercar un nou paràmetre: la representació equitativa en el govern de la ciutat dels dos bàndols. Aquesta estratègia diplomàtica dels oficials reials basada en l'equilibri pacificador, que no representa una novetat en la pràctica política peninsular ${ }^{40}$, va permetre consensuar amb una elit dirigent dividida la renovació anual de les magistratures urbanes. Una estratègia que, per altra part, suposava l'execució concreta de la política de reconciliació defensada -com hem dit anteriorment- pels oficials reials. Aquest caràcter improvisat es posa de manifest si realitzem un esforç comparatiu amb la intercessió monàrquica immediatament precedent, realitzada en

39 Ibid.

40 Hi ha exemples de com a la corona de Castella alguns municipis des de la segona meitat del segle XIV per regulació règia es governaven mitjançant la representació equitativa de dos cercles de poder enfrontats. Un exemple entre molts, en Trujillo (Extremadura) una sentència de Pedro I de 1357 regulava el repartiment dels càrrecs municipals entre els Bejarano y els Altamirano. Idèntica situació es produïa a la ciutat de Vitòria des de la Sentència de l'adelantat Pedro Manrique, la qual proveïa que els oficis del concejo es repartien de forma equilibrada entre els dos bàndols existents, els Ayala i els Callejas. En territori guipuscoà, a Mondragón, els Guraya i els Bañez gaudien d'un privilegi regi que els garantia un repartiment equitatiu dels oficis municipals, mentre que el ús i la costum regulava això mateix en el cas del municipi de Getaria. Vid. Regina Polo Martín, "Los reyes católicos y la insaculación en Castilla”, Studia historica, 17 (1999), pp.147-159. 
les eleccions municipals d'Alzira. En aquesta vila, la ingerència de la Corona es va efectuar a través de tres consellers reials -Vidal de Blanes, governador del regne, Joan Mercader, batle general i de l'advocat Guillem Saera- i es va manifestar amb uns trets i una forma de procedir molt diferent a la que tres dies després adquiriria a la ciutat de Xàtiva. Dites diferències es poden extraure a partir de les dades proporcionades per dos documents en particular, que estan però íntimament relacionats en tant que descriuen en què va consistir la intercessió dels oficials regis en les eleccions de la vila. El primer document és una lletra enviada pels tres consellers reials esmentats a Alfons el Magnànim el 16 de juny de 1416, en la qual a més a més d'exposar els fets es sol-licitava al monarca que atorgara certa provisió que li enviaven inserida ${ }^{41}$. Mentre que el segon document és precisament la lletra que un dia després el batle general va enviar al secretari reial Paulo Nicolás, en la que s'incloïa la lletra que prèviament els tres consellers reials havien adreçat al monarca amb la finalitat que li l'ha entregara a aquest i realitzara la publicació de la provisió reial sol-licitada ${ }^{42}$. A partir de la lectura crítica de tots dos documents i des d'una perspectiva comparativa podem establir una sèrie de diferències entre les eleccions alzirenyes de juny de 1416 i les de Xàtiva partint del fet comú d'haver estat mediatitzades per oficials reials.

Així doncs, la primera gran distinció és que la participació de la monarquia en la renovació dels membres del govern municipal alzireny no va ser improvisada sinó que ja havia estat prevista i organitzada durant el regnat de Ferran I, qui hauria donat facultat al batle general i a Guillem Saera per a arbitrar en les tensions sociopolítiques existents entre els veïns de la vila ${ }^{43}$. De fet, en novembre de 1412, pocs mesos després del seu accés al tron, Ferran I, informat precisament per tots dos oficials reials de com per «rahó dels oficis de la vila» hi havia grans desordres a Alzira, ordenava a aquells dos que reberen informacions i li notificaren quines provisions devia fer per tal d'enviar-se-les ${ }^{44}$. És a dir, que Ferran I delegava a Joan Mercader i a Guillem Saera la pressa de decisions al voltant de com gestionar els conflictes interns d'una de les viles més importats del regne. I de fet, això és el que li va confirmar en 1416 Joan Mercader al secretari reial Paulo Nicolás, a qui li reconeixia que tant ell com Guillem Saera ja havien estat personalment a la vila en diverses ocasions rebent informacions per comprendre l'abast i la naturalesa de la conflictivitat social generada a Alzira. A més, li informava que per atenuar possibles desordres públics ja s'havien publicat sentències i ordinacions al respecte del regiment de la vila, que serien

\footnotetext{
${ }_{41}$ ACA, RC, Cartes Reials, Alfonso IV [V], fol. 153r (16 de juny de 1416).

42 ACA, RC, Cartes Reials, Alfonso IV [V], fol. 156r (17 de juny de 1416).

43 L'estat actual de la investigació no permet identificar els bàndols existents en la vila, únicament hi ha notícies fragmentàries com en octubre de 1417 Joan Safàbrega, membre d'una de les cinc famílies més preeminents de la vila al llarg de la centúria (vid. Sandra BERnABEu BorJa, "Llinatges i poder local a l'Alzira del segle XV", Aragón en la Edad Media, 25 (2014) pp. 5-40, havia estat inculpat de crims. Uns crims als respecte dels quals el Magnànim va demanar al batle general informacions en secret vid. ACA, RC, 2664, fol.50v (23 d'octubre de 1417).

44 ACA, RC, 2401, fol.30v (12 de novembre de 1412): «que hauda per vos que lurs plena informació sobre açò nos certifiqueu per vostra letra quines provisions són necessàries quex façam ultra les farem e les vos trametrem tals com sien menester e vos altres volents...».
} 
notificades al nou monarca en el moment que aquell estiguera personalment en el regne de València ${ }^{45}$. Aquesta situació demostra com tot el procediment des de la pressa de decisions fins a l'execució de l'intervencionisme reial a les eleccions d'Alzira de 1416 va ser una empresa gestionada per Joan Mercader i de Guillem Saera, que va comptar, a més a més, amb el suport i la presència física de Vidal de Blanes, governador del regne. El que evidència, al capdavall, l'alt grau d'autonomia governamental i legitimitat pública assolit per aquests consellers reials per actuar en nom de la monarquia al regne fins i tot sense requerir el vist-i-plau del nou sobirà.

En segon lloc, cal subratllar que la solució recercada per dits consellers reials a Alzira va permetre mantenir a la seua elit dirigent la plena potestat municipal per a renovar als seus regidors, tenint en compte que Francesc de Martorell, Berenguer Serra, Bernat Perpinyà i Guillem Gombau, ciutadans de la vila, foren designats directament jurats aquella anualitat pels seus predecessors en el govern. Tot i que és cert, que els tres consellers reials exhortaren prèviament als magistrats per a què feren una cooptació que fora acceptada per tothom. Una solució que, per altra part, es va aconseguir amb simples pregàries per part dels oficials reials, és a dir sense exigir «remeys rigorosos» com a Xàtiva, diferència que potser atribuïda al fet que en aquella conjuntura particular la gravetat dels conflictes a Alzira fora menor que la prevista en la ciutat de València o a la ciutat de Xàtiva. És en el marc d'aquesta darrera previsió, en la que s'ha contextualitzar el per què les eleccions municipals a la vila d'Alzira en 1416 s'avançaren al dia 3 de juny, és a dir tres dies abans de la vespra de Pentecosta. En aquest sentit, tot i que a la missiva dels tres consellers reials enviada al monarca s'exposa com aquells decidiren avançar les eleccions per no prolongar el malestar social a la vila, Joan Mercader en la seua lletra a Paulo Nicolás li exposava que aquest avanç li permetia tant a ell com al governador del regne poder estar present el dia de les eleccions de la juraderia allí on fora necessària la seua presència, concretant explícitament que seria a la ciutat de Xàtiva o bé a la capital del regne.

En conjunt, la renovació del govern municipal per designació directa i la celebració de les eleccions fora del dia establert suposaven greus contradiccions amb la legislació electoral vigent a la vila. És en el marc d'autorització d'aquestes contradiccions legals en el que es produeix concretament l'intervencionisme regi en les eleccions de 1416 a Alzira. És a dir, el reconeixement per part del govern municipal alzireny de la legitimitat del monarca per a autoritzar una celebració de les eleccions al marge de la normativa legal era una manera d'acceptar l'arbitració del sobirà en les dinàmiques governamentals de la vila. Front aquesta situació, el major grau de conflictivitat existent a Xàtiva va impossibilitar recercar una solució semblant a la d'Alzira en tant que el patriciat urbà xativí va ser incapaç de gestionar autònomament la renovació anual del seu govern municipal. Aquesta circumstància va suposar que els oficials reials tingueren que improvisar un procediment electoral que es va desenvolupar al ritme que avançaven les negociacions en el si d'un patriciat urbà molt dividit.

45 ACA, RC, Cartes Reials, Alfonso IV [V], fol. 156r (17 de juny de 1416). 


\subsection{La controvertida ambaixada municipal a la cort reial i l'expulsió de la ciutat del noble Pere Maça}

En aquest sentit, i en part com a conseqüència del caràcter improvisat de les eleccions, com hem dit anteriorment, els oficials reials van advertir al monarca com era molt probable que li arribaren súpliques tant dels membres del bàndol dels Castellar com per part dels Sanç per tal que anul'lara l'elección ${ }^{46}$. I de fet, pocs dies transcorrerien per verificar que les previsions dels oficials reials es feien efectives. Doncs, al voltant del 22 de juny, Lluís de Lloris, el jurista Pere Feliu i Dalmau de Fluvià encapçalaren una missatgeria a la cort del rei per tractar la intromissió reial en els afers del municipi, com recull una missiva del govern municipal de la ciutat de València ${ }^{47}$.

En certa mesura, aquesta previsió dels oficials reials gairebé era inevitable, doncs els dos bàndols antagònics que havien estat incapaços de negociar una elecció sense la intromissió reial es veien obligats per l'autoritat règia a compartir òrgans de govern, que no anaven a ser mediatitzats per cap dels bàndols. Per tant, el malestar sociopolític pel repartiment del poder municipal anava a continuar vigent a Xàtiva, ja que aquella renovació dels càrrecs públics no havia acabat de convèncer a l'elit dirigent ${ }^{48}$. Especialment, en aquell repartiment havia resultat perjudicat el bàndol partidari dels Vilaragut, que l'any anterior havia controlat tots els ressorts de poder municipal i que a partir d'aleshores veuria reduït notablement el seu control sobre el govern de la ciutat. Seria precisament els membres d'aquesta facció, és a dir representants del govern anterior, els que haurien autoritzat dita ambaixada per fer les pertinents protestes al monarca, animats pel govern municipal de la capital on almenys hi havia dos membres pro-urgellistes ${ }^{49}$. Doncs els jurats de la ciutat de València, el dia 6 de juny, dia de les eleccions, justificaven davant del seu consell general que s'havien enviat missatgers a Xàtiva per temor que allí s'iniciaren bregues, que esdevingueren en bàndols ${ }^{50}$. Així mateix, s'observa com el posicionament inicial del govern de la capital del regne al respecte de la intervenció dels oficials reials en les eleccions de Xàtiva foren tractades, segons una missiva adreçada als missatgers de la ciutat en la cort reial, en termes de desaforament. De fet, en aquella lletra es donava instruccions als missatgers de la ciutat de València per a què donaren suport $a$ l'ambaixada enviada des de Xàtiva a la cort del rei ${ }^{51}$.

\footnotetext{
46 ACA, RC, Cartes Reials, Alfonso IV [V], fol. 148 a-b-c (13 de juny 2016).

47 AMV, L1M, $\mathrm{g}^{3}-13$, fol. 123v (22 de juny de 1416).

48 En aquest sentit, caldria reflexionar el per què el sobirà o els dits consellers reials no van plantejar un govern municipal en què ambdues faccions quedaren excloses. Doncs, una possibilitat factible seria que no hi havia un nombre d'individus aptes a dits oficis que foren «comuns», tot i que es cert que la meitat de la conselleria si estava constituïda per aquests, al voltant del quals no s'especificà al detall com van ser elegits.

49 AMV, L1M, g $\mathrm{g}^{3}-13$, fol. 115v (5 de juny de 1416).

${ }^{50}$ AMV, MC, A-26, fol.147r. (6 de juny de 1416): «Explicaren al present consell los honorables jurats com ells havien entès que en la ciutat de Xàtiva se fahia gran ajust de gentils hòmens per raó de la elecció de jurats que lla·s devia fer tal dia com huy és temessen que alcuna brega no si esdevingués de la qual sortís bando entre $\cdot 1 l s$ de que·s poria seguir gran dan a la cosa pública...».

51 AMV, L1M, g $\mathrm{g}^{3}-13$, fol. 123v (22 de juny de 1416).
} 
Una missatgeria que en menys d'un mes va quedar desproveïda de suport institucional. Doncs, el consell general de Xàtiva reunit el 4 de juliol sota la coacció de Pere Maça deixava de reconèixer aquella ambaixada com a representant del govern municipal, i, a més a més, després d'una votació entre els membres de dit consell es va decidir que si aquells tenien lletres de creença al seu favor per part del govern precedent des d'aquell moment quedaven revocades ${ }^{52}$. D'aquesta manera, els jurats i el consell de Xàtiva es desvinculaven per complet de les protestes efectuades per part dels missatgers de la ciutat enviats pel govern de l'any anterior davant del monarca per la forma en què s'havien desenvolupat les eleccions municipals de feia un mes. Cal assenyalar que aquesta renúncia es va produir en un consell general la convocatòria del qual no s'ajustava a les ordinacions de la ciutat, en tant que únicament eren presents dos dels quatre jurats. Situació per la qual els magistrats presents, Francesc Bosch i Berenguer March, protestaren al monarca ja que s'havien vist pressionats a convocar-lo davant el manament $\mathrm{i}$ les penes imposades per aquell de Joan Rotlà, lloctinent del governador dellà el Xúquer.

A més a més, aquesta circumstància es produïa poc més o menys deu dies després que els missatgers de la ciutat de València hagueren retirat també el suport a dita ambaixada $^{53}$. Aquest canvi d'actitud del govern de la capital s'ha de contextualitzar en una conjuntura de debats interns en el si de la seua l'elit dirigent en què estava en joc demostrar la fidelitat d'aquella al nou monarca, qui s'hauria plantejat emetre llistes de ciutadans i cavallers de la ciutat sospitosos per a evitar que aquells participaren en el govern municipal. De fet, en aquest marc i per a intentar dissuadir al sobirà, el batle general ordenava que el Magnànim fora informat com en el consell general de la ciutat de València del 23 de juny els jurats havien pres la decisió de fer retornar en deu dies als seus missatgers en la cort reial, als quals s'havia donat instruccions de no intervindre en assumptes que enutjaren al monarca ${ }^{54}$. Tot $\mathrm{i}$ que de forma explícita no es va referència al cas concret en el qual la intromissió dels missatgers de la ciutat de València hauria molestat al Magnànim es pot relacionar amb el fet del suport que aquells estarien donant a l'ambaixada feta per la ciutat de Xàtiva ${ }^{55}$. Fora com fora, el cert és que Lluís de Lloris, Pere Feliu i Dalmau de Fluvià es van veure desproveïts del suport institucional que havien comptat en un principi, possiblement per les pressions efectuades per la Corona que va provocar que aquests missatgers es quedaren sols defensant la plena l'autonomia de Xàtiva per a elegir als seus representats en els càrrecs públics municipals.

Per altra part, al mateix temps que la monarquia debilitava les protestes per la seua arbitració en la renovació del govern municipal, en el marc de la justícia Vidal de Blanes, governador del regne, es feia càrrec de mitigar les bandositats que afectaven a la ciutat.

52 ACA, RC, Cartes Reials, fol. 200r (4 de juliol 1416).

${ }^{53}$ ACA, RC, Cartes Reials, fol.166r (23 juny de 1416).

${ }^{54}$ ACA, RC, Cartes Reials, Alfonso IV [V], fol.166r (23 juny de 1416). La lletra enviada pels jurats valencians als seus missatgers en la cort no esmenta en cap moment que no deuen procurar enutjar al monarca vid. AMV, LM, g⿳⺈-13, fol. 124r (23 de juny)

${ }^{55} \mathrm{Vid}$. nota 50. 
En aquest sentit, el 10 de juliol, assessorat pel batle general, pregava al noble Pere Maça de Liçana i al cavaller Francesc Bellvís, membre també del bàndol dels Centelles, que eixiren de la ciutat de Xàtiva i dels seus termes fins que reberen ordre del contrari, acusant-los de donar «gran torbació en la dita ciutat, volen portar a vostra volentat lo regiment de aquella de què prenets massa gran càrrech e por se'n seguir tubulació e turbació molt gran de l'estat pacíffich de la dita ciutat e d'aquest regne... $\rangle^{56}$. És a dir, sis dies després de què Pere Maça es presentara en el consell general de Xàtiva i pressionara per a què la ciutat es desvinculara de la seua ambaixada a la cort reial, aquell rebia ordre del governador de no entrar en aquella ciutat. La imposició d'aquella primera mesura va ser qualificada pel governador com un mal menor als seus actes, que requerien la imposició de majors penes, les quals rebria de no obeir els seus manaments. De fet, sobre dit cas, el governador escrivia al monarca advertint-lo que havia proveït així per a guanyar temps i que aquell li poguera donar instruccions si ho considerava oportú abans d'imposar penes majors. Al mateix temps, el governador animava al lloctinent i al justícia de Xàtiva a participar en la seua lluita contra els bàndols que afectaven a dita ciutat, tenint en compte que això determinaria el grau de conflictivitat en el regne durant la resta del regnat del nou monarca. Doncs, Vidal de Blanes els reconeixia com malgrat el poc respecte que li mostraven dits membres dels bàndols ell persistiria contra aquells en tant que la ciutat de Xàtiva estava

[...] en mal estament per rahon de aquestes gents de les partides dels bandos, òlim de aquesta ciutat, car veem fer algunes appareles, los quals són molt sospitosos de debats e bregues entre ells, e jatssia nosaltres los haiam dats límits e fetes altres provisions per relevar escàndels e perills, emperò conexem que porten a nosaltres poqua reverència, ens mostren poqua temor, mas per tot açò no romandrà que nosaltres no y retem nostre deute segons nostra possibilitat, emperò com sabets en aquests principis va molt a repòs del regne 0 per lo contrari per tal conssultam vostres grans savieses de les dites coses... ${ }^{57}$

\subsection{Les segones eleccions municipals: 1 d'agost de 1416}

A inicis d'agost, dos mesos després d'haver realitzat les eleccions del govern municipal i dies després d'haver expulsat de la ciutat a Pere Maça i a Francesc Bellvís, és tornaren a repetir les eleccions dels jurats i dels consellers. En conseqüència, el gran esforç diplomàtic dels oficials reials per conformar un govern equitatiu entre dos cercles de poder confrontats al municipi va adquirir un caràcter temporal, doncs el govern resultant únicament va romandre en el poder durant dos mesos. Es dedueix com aquesta nova

56 ACA, RC, Cartes Reials, Alfonso IV [V], fol. 211r (10 juliol de 1416). L'assignació de Francesc Bellvís al bàndol dels Centelles es basa en què al llistat de membres d'aquest partit elaborat per R. Narbona es troba Joan Bellvís i Guillem Bellvís molt possiblement familiars d'aquell vid. R. NARBONA, "L'interregne a València...p. 773.

57 ACA, RC, Cartes Reials, Alfonso IV [V], fol. 209r (10 de juliol de 1416). 
renovació del govern xativí es va efectuar sota iniciativa d'una part de l'oligarquia municipal, doncs els recents elets magistrats de Xàtiva alhora que notificaven al monarca que havien feta l'elecció de la juraderia i del consell de forma pacífica el dia un d'agost es mostraven agraïts per «la gran gràcia e mercè que hauts feta a aquesta ciutat». És a dir, lluny d'apel·lar el gran contrafur que suposava repetir unes eleccions municipals en una mateixa anualitat, els jurats de Xàtiva es mostraven agraïts amb una decisió que sens dubte anava en favor dels seus interessos, tot i que aquells al ludien a la gràcia rebuda per la col·lectivitat, la ciutadania. Mentre que la part de l'elit dirigent perjudicada, representada pels cavallers Lluís de Pertusa i Corberan d'Alet, va protestar aquella mesura, el que va obligar als oficials reials encarregats d'executar dita elecció -en aquell cas el lloctinent del governador, i l'assessor d'aquell Domingo Mascó- a respondre per escrit a les al·legacions presentades per aquells, tot i que després els dits oficials notificaven al monarca com les seues objeccions no havien suposat un major problema $^{58}$.

Amb tot, aquella nova elecció de govern va estar regulada per una provisió reial que va ser enviada directament al governador del regne $i$ als jurats que deixaven el càrrec ${ }^{59}$. En aquest sentit, resulta evident que aquella nova disposició era favorable als membres del bàndol dels Centelles, doncs del govern municipal resultant va sorgir la súplica al sobirà per a què el cavaller Jofré de Vilarig, reconegut centellista, fora elegit justícia per dos anys d'aquella ciutat, suspenent així durant aquest període les eleccions corresponents a dit càrrec. I de fet, el 16 de desembre el monarca designava al dit cavaller com a justícia de Xàtiva però, a més a més, el va investir de tot el seu poder en matèria de justícia a l'atorgar-li també el grau de virrei i lloctinent seu en la ciutat i en el terme general d'aquella ${ }^{60}$. D'aquesta manera, al igual que ja havien fet altres monarques, es creava un càrrec de lloctinent $i$ virrei en un territori concret amb la finalitat d'incrementar notablement el respecte a la seua autoritat i competències per facilitar-li la lluita contra les bandositats. Ara bé, en aquest cas les amplies atribucions conferides a un cavaller que havia participat en les lluites de bàndols va resultar un autèntic fracàs, doncs en pocs mesos es va guanyar la fama pública de no ser «hom pus pacífich», situació davant la qual el Magnànim va reaccionar assignant-li al notari Joan Gallach com assessor ${ }^{61}$.

\section{El repartiment equitatiu de poder entre els bàndols 1417-1427}

Per altra part, cal assenyalar que el nou govern resultant de les eleccions d'agost de 1416 va romandre fins a la resta de l'any polític. Doncs, com era habitual la renovació de l'executiu de govern i del consell en 1417 es va celebrar en la vespra de Pentecosta i en aquella ocasió novament la Corona va intercedir per a què es produira una representació equitativa dels dos bàndols en el govern de la ciutat. En concret, aquella anualitat el

58 ACA, RC, Cartes Reials, Alfonso IV [V], fol. 244r (7 d'agost de 1416).

59 ACA, RC, Cartes Reials, Alfonso IV [V], fol. 243r (3 d'agost de 1416).

60 ACA, RC, 2561, fol.157v (16 desembre de 1416).

${ }^{61}$ ACA, RC, 2561, fol.188r (20 d'abril de 1417). 
monarca tenia pensat estar present personalment en les eleccions de Xàtiva, però davant possibles contratemps va manar al seu conseller Martí de Torres que ell mateix -en cas que els regidors de Xàtiva no volgueren prorrogar uns deu o quinze dies les eleccions a l'espera de la seua l'arribada- designara directament els candidats a la juraderia per escrit. És a dir, el Magnànim va delegar a Martí de Torres la confecció d'una ceda reial sota l'única instrucció de tindre cura de realitzar un repartiment dels càrrecs equilibrat entre els dos partits.

[...] e informarà diligentment de les pus bones e sàvies persones que porà trobar per al dit regiment, axí de una part com d'altra, e farà que en cascú dels oficis haia, si possible és, tants de una part com d'altra, o alments que entre tots los oficis siam mig per mig e nomenadament en cascú ofici, dar-los ha per escrit als dits jurats e consell dient-los com lo dit senyor vol en tot cas que los allí nomenats vingués en los dits oficis, que si no ho fehien ell ha manament per al batle que no acapte ne conferme alcuna elecció que facen, e encara de procehir segons los pora mostrar per sa comissió, contra aquella qui desviar o torbar volran que lo voler del dit senyor no se'n seguesca, rex Alfonsus ${ }^{62}$.

Aquest manament no es va fer afectiu, en tant que els magistrats de Xàtiva accediren a esperar al monarca, el qual encara va demanar una segona pròrroga de deu dies més ${ }^{63}$. Tot plegat, les eleccions del govern municipal de Xàtiva de 1417 es van efectuar sota la presència del Magnànim, el qual va repartir el poder municipal entre els dos bàndols. Ara bé, la presència del sobirà no va estar exceptuada de conflictivitat com es pot deduir a partir d'una provisió de remissió de penes del monarca en maig de 1418, la qual il·lustra com mentre el rei estava present a la ciutat de Xàtiva els cavallers Lluís de Pertusa i Jaume de Malferit junt a Pere Sanç, Joan Guerau, Bernat Ferrer, Joan Argent, Pere Enyec i Jaume, l'escuder de Miquel Sanç, van realitzar «certs crims» ${ }^{64}$. És a dir, Lluís Pertusa, qui en agost de 1416 havia protestat al respecte de la repetició de les eleccions dels jurats i del consell, junt a membres del bàndol dels Sanç haurien estat involucrats en crims mentre el Magnànim hi era present a la ciutat. La manca de dissuasió davant la presència del monarca en la ciutat i la possible vinculació de Lluís Pertusa al bàndol

62 ACA, RC, 2664, fol.15r (26 de maig de 1417). Amb aquest mateix argument, sota l'expressió de «concòrdia e equitat» esgrimí el Magnànim als jurats i al batle local de Xàtiva en la carta de creença que havia expedit en favor del seu conseller reial amb la finalitat que executaren allò que aquell els diria vid. ACA, $\mathrm{RC}, 2664$, fol.17r (26 de maig de 1417).

63 ACA, RC, 2563, fol.18r (10 de juny de 1417).

64 ACA, RC, 2563, fol.164r (31 de maig de 1418). Davant aquells crims, el monarca en un principi va establir que aquells comparegueren davant seu amb la condició de que si no ho feien a partir de cert termini foren sentenciats a mort. No obstant això, un any després el monarca els oferia el perdó a canvi que no entraren en la ciutat ni en els termes d'aquella durant un any. Període de temps, que fou reduit verbalment pel monarca a set mesos, complits els quals el monarca en un document a data del 21 de gener de 1419 els permetia novament poder entrar en la ciutat $i$ en els termes. vid. ACA, RC, 2564, fol.180r (21 de gener de 1419). 
dels Sanç -almenys els crims de 1417 permeten relacionar-lo amb aquell partit- podria estar indicant com aquells constituïen el grup de poder afí als Vilaragut. Fora com fora, el cert és que l'elecció realitzada pel monarca no va acabar amb els problemes interns del govern municipal, com demostra el fet que a penes un mes després de l'elecció una part dels jurats i dels consellers recusaven reunir-se en consell particular i general. Davant aquesta situació, el sobirà donava ordre a Joan Rotlà, lloctinent del governador, i a Nicolau Martí, justícia de Xàtiva (possiblement lloctinent o substitut de Jofre de Vilarig), que exhortaren als oficials municipals d'assistir al consell general de la ciutat, tot advertint que aquell devia ser convocat d'acord amb la normativa vigent. Per altra part, al mateix temps, el rei manava expressament que en cap cas en els consells de dita ciutat es revocaren els missatgers d'aquella enviats a la seua cort, en tant que segons considerava el monarca eren «persones bones e favorables e amants nostre servir» ${ }^{65}$.

Desconeixem que va ocórrer durant aquells mesos, tot i que es pot certificar que els problemes de governabilitat de la urbs continuaren creixent. Doncs, en març de 1418, Joan Mercader en una lletra adreçada al Magnànim confessava que la divisió igualitària entre dues parts contràries dins del govern municipal de Xàtiva havia impossibilitat que el consell general d'aquella ciutat fora capaç de prendre decisions. En aquell cas, en concret, no s'havia pogut acordar si acceptar o no una provisió reial al voltant d'un greuge de corts, tot i haver realitzat una votació nominativa entre tots els membres de dit consell per exigència directa del propi monarca. Així mateix, segons el batle general, aquestes dificultats governamentals eren representatives d'una ciutat on tots els habitants d'aquella, inclòs és de baixa condició, es trobaven dividits en dos parts de forma molt igualitària, el que impedia que una de les faccions s'imposara a l'altra.

[...] que en aquestes maleytes de affecions sobre lo regiment de aquesta vostra ciutat són axí mig per mig partides, que us meten vostra ciutat e tot lo poble en dues parts quasi eguals axí en la gent de estament com en la baxa, que no sobre puja la una part a la altra de no res o fort poch... ${ }^{66}$

Davant aquesta realitat, Joan Mercader confessava al monarca que «segons opinió de molt e molts a vos és necessari usar de remeys reyals ${ }^{67}$, convidant així al Magnànim a intervindre de forma més decidida i contundent per pal-liar aquella insostenible situació que feia gairebé ingovernable la segona ciutat més important del regne. No obstant això, en les següents eleccions de la juraderia, les de 1418, el monarca tornava a persistir en el repartiment de poder i en la conveniència d'un govern municipal conformat per ambdues posicions contraposades i irreconciliables. En aquest sentit, en el mes de maig donava instruccions a Joan Mercader per a què seguira la seua provisió amb la finalitat expressa

\footnotetext{
ACA, RC, 2562, fol.101r (15 juliol de 1417); ACA, RC, 2665, fol. 178v (10 de juliol de 1417).

ACA, RC, Cartes reials, Alfonso IV [V], fol. 722r (30 març de 1418).

67 Ibid.
} 
que «lo regiment de la dita ciutat sia posat en egualtat» ${ }^{68}$. Pel que fa a la disposició que va regular dita elecció, tot i que no s'específica en què consistia, el monarca ordenava que fora secreta, el que permet plantejar la hipòtesi de què possiblement es tractara de la nòmina de candidats a partir de la qual es devia realitzar l'elecció dels jurats, és a dir una ceda reial. Dos dies després d'enviar aquestes instruccions, el monarca donava llicència al batle general $i$ al lloctinent del governador, per a procedir contra les persones i els béns d'aquelles que es preparaven amb armes amb motiu de la celebració de les eleccions dels jurats. Al mateix temps, el monarca matisava les ordres de la lletra anterior enviada al batle general, assenyalant que únicament en cas que el consell de la ciutat de Xàtiva no es posara d'acord en l'elecció es procedira a realitzar aquella seguint l'esmentada provisió reial ${ }^{69}$. I així ocorreria, tenint en compte que el 30 de juliol d'aquell any Alfons el Magnànim agraïa a Joan Rotlà, lloctinent del governador, al justícia $i$ als jurats de Xàtiva que hagueren respectat «les ordinacions e nominacions de paraula per nos a vosaltres donades e fetes concernents lo bon regiment e tranquille estament d'aqueixa ciutat e terme de aquella.... ${ }^{70}$. L'expressió «nominacions de paraula» al·ludiria a com aquella juraderia va ser elegida mitjançant una ceda reial dictada pel propi monarca. Aquesta implicació tan directa del sobirà es produiria per tant en un context marcat per la insostenible conflictivitat social, com mostra el fet que junt a aquell agraïment el monarca els donara ple poder per a interposar-se «rigorosament» en les bandositats i llicència per expulsar de la ciutat Xàtiva a aquells i als valedors d'aquells que no volgueren sotmetre's a pau i treva ${ }^{71}$.

L'any següent, en maig de 1419, el Magnànim després de reconèixer als magistrats el bon govern per ells desenvolupat, que havia contribuït al repòs de la ciutat, els animava a continuar en aquesta línea en la nominació de candidats a les noves eleccions de la juraderia. Així doncs, els donava instruccions de nominar a persones bones i afectes a la monarquia i al servici del bé públic al mateix temps que els ordenava que procediren a realitzar l'elecció segons cert fur i seguint l'exemple de com la Corona havia realitzat les eleccions de l'anualitat anterior. Amb aquest mateix propòsit, el Magnànim va escriure a Joan Rotlà, notificant-li les instruccions que havia donat als jurats (especialment a Ramon Sanç i a Pere Feliu), però a més a més ordenant-li que vetllara, per una part, per a què en l'accés als oficis tingueren preferència persones al menys parcials possibles. Per altra part, el dit lloctinent del governador devia procurar que les eleccions no foren causa de nous conflictes, fet pel qual l'autoritzava a expulsar de la ciutat a qualsevol cavaller que considerara sospitós de provocar enfrontaments en aquella ${ }^{72}$. És a dir, que front al

\footnotetext{
68 ACA, RC, 2664, fol.101r (19 de març de 1418).

${ }^{69}$ ACA, RC, 2664, fol.101v (31 de març de 1418).

70 ACA, RC, 2641, fol.162v (30 de juliol de 1418).

71 Ibid.

72 ACA, RC, 2666, fol.164v (28 de maig de 1419): «preferides persones lo més comuns e menys parcials que sia possible, e en totes maneres siats atent que sobre la dita elecció o per causa de aquella no seguexa alteració o rumor al ora en la dita ciutat [...] foragitets de la dita ciutat aquells dels cavallers e homes de paratge que us serà vist poguessin o asseiassen empatrar o pertorbar la bona direcció de les dites coses...».
} 
discurs de representació equitativa dels bàndols en el govern de la ciutat el Magnànim en maig de 1419 donava ordres al dit lloctinent de què participaren persones no parcials. Un manament contradictori amb el discurs polític projectat sobre la pràctica governamental, tenint en compte que per iniciativa pròpia i fins que ell considerara oportú, el Magnànim va atorgar a la ciutat de Xàtiva una provisió el 18 de setembre d'aquell any que introduïa una modificació en el sistema d'eleccions per a regular la representació equitativa dels bàndols en l'executiu de govern ${ }^{73}$. Doncs, segons reconeixia explícitament el monarca en dita provisió, el fet que una de les dues parcialitats tinguera el control en exclusiva del poder municipal, excloent totalment als membres de l'altre bàndol, provocava nous conflictes entre ells que, en conseqüència, perjudicaven al regiment de la ciutat. Conscient d'aquesta realitat, el sobirà va emetre aquella pragmàtica que recollia dos procediments diferents adaptats a la variable anual de la representació estamental. És a dir, cada un dels procediments responia a si l'alta magistratura urbana anava a estar constituïda exclusivament per quatre ciutadans o per contra hi hauria representació de l'estament de cavallers i homes de paratge ${ }^{74}$, situació que com en la resta de ciutats i viles del regne - exceptuant la ciutat de València-s'alternava anualment sempre i quan hi haguera un nombre determinat d'homes de paratge habitant el municipi. En aquest sentit, l'any que corresponia elegir a quatre magistrats ciutadans, els tradicionals dotze candidats que participaven en l'elecció es dividirien en dos bacins d'aigua dins de cada un dels quals serien introduïts sis redolins, que contenien el nom dels individus de cada parcialitat i d'altres no parcials (anomenats a la documentació comuns). No queda clar en la redacció de la provisió si a cada bací d'aigua correspondria una parcialitat junt a persones no parcials, o més bé directament un bací estaria constituit per persones parcials $i$ altre per comunes. Fora com fora, de cada un dels dos bacins s'extraurien dos redolins i els noms de les persones d'aquells serien publicats com a jurats aquella anualitat pel batle local i pel justícia. Per altra part, l'any que pertocava elegir a un cavaller, es constituirien tres bacins, dos per als ciutadans com en dit anteriorment $i$ un que únicament inclouria el nom de sis cavallers o homes de paratge. D'aquest darrer s'extrauria un redolí, el nom de la persona contés en aquell seria nomenada jurat pels cavallers i generosos mentre que pels ciutadans d'un bací s'extraurien dos redolins i de l'altre únicament un.

Ara bé, per a què aquesta provisió tinguera l'efecte desitjat era necessari que els electors realitzaren una selecció de candidats a la magistratura lliure de recels o estratègies que permeteren apropiar-se els oficis a certes famílies. Per aquest motiu, el Magnànim incloïa en la provisió que els jurats i els consellers de la ciutat de Xàtiva eren els màxims responsables de realitzar nominacions no parcials, de forma que en cas de què es comprovara el contrari les penes imposades recaigueren sobre ells. Tot plegat, d'aquesta provisió s'entreveu els esforços de la monarquia per recercar una

3 ACA, RC, 2751, fol. 128r-v (18 de setembre de 1419).

74 A la ciutat de Xàtiva el nombre de places de jurats era de quatre, de les quals tres estaven reservades a persones de condició ciutadana, mentre que la quarta plaça en anys alterns era desenvolupada bé per un individu de condició ciutadana o bé d'extracció de cavallers o homes de paratge. 
mètode d'elecció que preservant l'autonomia ciutadana per a elegir els seus candidats fora capaç d'aconseguir evitar l'exclusió del govern municipal d'un dels bàndols. $\mathrm{Al}$ mateix temps, la divisió entre els candidats ciutadans en dos bacins i no als cavallers i generosos evidència com les bandositats a la ciutat de Xàtiva a les altures de setembre de 1419 tenia un marcat component ciutadà, o almenys l'escissió entre ciutadans era més visible que no en l'estament de cavallers i generosos que solien participar en les eleccions municipals.

Amb tot, la nova provisió tampoc va acabar de resoldre l'hostilitat social existent. Doncs, el 8 de juny 1425, el monarca es feia resol com en les eleccions dels jurats i del consell de Xàtiva s'haurien realitzat sense tindre en compte els manaments de la monarquia. Per tant, amb la finalitat d'intervindre davant aquella inobediència sol-licitava al governador del regne més informació al respecte ${ }^{75}$. Aquesta voluntat per intercedir en les eleccions, com argumentaria deu dies després, tenia el deure de realitzar-la en tant que «volem e és necessari generalment entre nostres vassals e sotsmeses pau e concòrdia». Així doncs, tot i que desconeixem a qui dirigia aquella missiva del 8 de juny -al més probable és que fora al batle general- el monarca expressava que amb la finalitat d'evitar possibles confrontacions al respecte de la conformació del govern de dita ciutat, havia pensat que la millor opció era suspendre les eleccions. És a dir, el Magnànim opinava que per evitar la confrontació que suscitaven les eleccions el millor era anul·lar aquelles i que els regidors i consellers de l'any anterior governaren també aquella anualitat. No obstant això, el Magnànim no ho ordenava sinó que ho expressava com una proposta a l'espera del judici de valor del receptor de la missiva, a qui pregava que en cas de que considerara una opció més adequada l'advertira, però en cas contrari que executara la no renovació del govern municipal ${ }^{76}$. No es constata en la documentació com es va procedir finalment a la constitució del govern xativí de 1425 , però si que l'any posterior, en concret el 13 de maig de 1426, el monarca va proveir que el justícia, els jurats junt als consellers i prohoms de la ciutat realitzaren una elecció per a nomenar a electors de jurats, qui al seu temps nominaren els candidats a la juraderia de 1426. Així doncs, el monarca justificava aquesta provisió fent novament menció a la necessitat d'evitar confrontacions ${ }^{77}$. Tot i desconeixem com es van desenvolupar les eleccions d'aquell juny de 1426, si es documenta com a partir d'aquell any el sistema electoral municipal patiria irreversiblement una acusada transformació paral lela a l'esdevinguda a la ciutat de València, on s'introduiria aleshores la ceda reial com a mecanisme de nominació de candidats a la màxima magistratura urbana.

\footnotetext{
75 ARV, RC, 232, fol. 131r (8 de juny de 1425): «la elecció feta de jurats e consell e altres oficis de la ciutat de Xàtiva se serien servades algunes pràctiques contra la forma per nos ordenada a bé e repòs de la dita ciutat...».

76 ARV, RC, 35 (18 de juny de 1425), fol. 6r: «es vist a nos e a nostre parer molt saludable per tolre e cessar totes novitats e escàndels que los jurats e consellers de la dita ciutat del any passat regissen e adminitrassen en la dita ciutat lo regiment per lo present...».

77 ARV, RC, 40, fol. 30r (13 de maig de 1426): «per lo pacífich estament e quietut de la dita ciutat e benavenir de la cosa pública».
} 
Doncs, com ja és vell conegut per la historiografia, el 31 de març de 1427, el monarca va atorgar a la ciutat el privilegi d'insaculació, publicat per Juan Antoni Barrio en $1991^{78}$. Amb aquell privilegi el monarca, que expressament en diverses ocasions fa referència a la necessitat d'imposar pau i concòrdia, recercava a curt termini establir un sistema electoral estable, que no fera necessària l'arbitració directa de la Corona anualment per sufocar les tensions i confrontacions habituals entre l'elit dirigent de la ciutat. De fet, en abril de 1438, l'infant Joan -en qualitat de lloctinent general- renovava la vigència del privilegi de sac i sort recordant quines foren les motivacions del Magnànim a l'ordenar aquell:

[...] lo senyor rey en temps passat, zelant lo bo e pacífich estament de la dita ciutat e veent que gran part de les sinistres e inconvenients que's seguien en aquella pervenien de la cobdícia, que molts dels ciutadans e habitadors de la dita ciutat havien de haver e retenir los dits officis e regiment de aquella a fi d'oprimir et supeditar lurs contraris a mà de los dits officis, ordenà, segons sabets, loablement que per esquivar abusos e los dits e altres inconvenients fos feta nominació de totes les persones de la dita ciutat que eren bones, hàbils e suficients a regir e administrar los officis d'aquella, e de les persones axí com dit és nomenades feu reparticions, metent los noms de aquelles en tants sachs com són los officis de la dita ciutat... ${ }^{79}$

Una renovació amb la qual la monarquia donava continuïtat a una insaculació considerada «molt útil e profitosa al repòs e bon estament de la ciutat...» ${ }^{80}$. Valoració que explica la seua continuïtat a Xàtiva ${ }^{81}$ i el fet que des de la seua introducció en aquella el sistema de sac i sort s'anara difonent al llarg de les centúries per tota la Corona d'Aragó.

\section{Conclusions}

Més enllà de la possible parcialitat de la documentació reial, el present estudi il·lustra com existeix una correlació durant el regnat d'Alfons el Magnànim entre el primer municipi

\footnotetext{
78 Juan Antonio Barrio Barrio, "La introducción de la insaculación en la Corona de Aragón. Xàtiva, 1427. Transcripción documenal", Anales de la Universidad de Alicante, 8 (1990-1991), pp. 99-114.

79 ARV, RC, 68, fol.108r (8 d'abril de 1438). Aquesta intencionalitat explica que, a mode de mesura per dissuadir les bandositats, s'incloguerà entre les clàusules d'impediment a l'exercici dels càrrecs públics la participació públicament en bandositats vid. J. A. BARRIO BARRIO,"La introducción de la insaculación...p. 109.

80 ARV, RC, 68, fol.108r (8 d'abril de 1438).

81 Cal assenyalar com de forma excepcional en la insaculació va ser suspesa en l'any 1464. Aquella anualitat Joan II -immers en el moment més àlgid de la guerra civil catalana- va preferir designar directament a l'executiu de govern. Aquella mesura que el sobirà considerava extraordinària tenia la finalitat de garantir que tots els oficials municipals foren persones adeptes a la monarquia, el que per altra part evidenciaria que el monarca considerava sospitoses a persones insaculades. En aquella conjuntura precisa, el monarca concedí l'alta magistratura urbana a Bernat Sanç, Lluís Gallach, Vicent Ferrer i Bernat Palomar vid. ARV, RC, 288, fol.122r (22 d'abril de 1464).
} 
al regne de València que mostra signes d'ingovernabilitat a causa de les bandositats amb el primer que, una dècada després, rebrà d'aquella el privilegi d'insaculació. Així mateix, el cas particular de Xàtiva permet observar dues realitats significatives, per una part, l'extraordinària autonomia i capacitat de pressa de decisions polítiques assumides pels consellers reials Joan Mercader, batle general, i per Vidal de Blanes, governador del regne, en absència de monarca. Fet que posa en relleu la seua funció governamental en el regne com a interlocutors directes entre el monarca i els membres més destacats del patriciat urbà. I, per altra part, Xàtiva mostra com els esforços per a celebrar eleccions municipals van obligar a una elit dirigent enfrontada a assumir la necessitat de negociar amb la Corona les condicions en què es devia efectuar la renovació del govern de la ciutat. Seria, per tant, a inicis del regnat del Magnànim quan la capacitat de negociació de l'autoritat règia amb les institucions de govern municipal s'aniria imposant davant un patriciat urbà dividit. Circumstància que va permetre un enfortiment de la monarquia, la qual adquiriria com a pròpia la capacitat de repartir el poder polític al municipi sota la forma d'arbitratge en les bandositats. Al cap i a la fi, l'equilibri de poder entre ambdues faccions en el si del govern municipal seria el ideal polític inicial que argumentaria la monarquia per a justificar la seua intervenció en les eleccions municipals de Xàtiva, una intercessió cada vegada més demandada per una part de l'oligarquia patrícia.

Per altra banda, aquesta ingerència de la Corona en les eleccions va provocar protestes per part d'un sector de l'elit dirigent, normalment el més perjudicat, que va canalitzar la defensa dels seus interessos particulars -especialment el manteniment del poder gaudit durant dècades dins de la societat política local- sota el discurs de la defensa de furs $i$ privilegis de la ciutat i del regne. Doncs, l'elit urbana no denuncia de forma conjunta la intromissió de la monarquia en el municipi, sinó que es troben posicionaments contraposats en funció de si la política intervencionista afavoreix o no les seues ambicions personals o de grup. Per tant, darrere de les inicials protestes contra la ingerència règia continuava existint una lluita pel poder entre l'elit dirigent, circumstància que obliga a dissociar la defensa de privilegis del regne amb la defensa de l'autonomia ciutadana. De fet, en el moment que la monarquia va ser conscient de què la lluita en el si del patriciat urbà per aconseguir el poder persistiria més enllà de la seua intercessió, començarà a instrumentalitzar en benefici propi la seua capacitat per a intervindre en les eleccions municipals. Per tant, serà en un segon moment quan l'arbitratge monàrquic esdevindria en una pràctica política que la Corona utilitzaria especialment per a configurar governs municipals predisposats a satisfer les seues demandes financeres o militars. Així mateix, la seua facultat per a facilitar l'accés dels individus a les magistratures urbanes faria que la intercessió monàrquica en el municipi s'integrara dins del sistema de gràcies règies, que tradicionalment la monarquia solia concedir als individus -o familiars d'aquells- en retribució dels serveis (administratiu, financer, militar...) prestats a la Corona.

Finalment, la forma de procedir inicialment de la monarquia a Xàtiva és el paradigma que mostra com després de l'accés al tron dels Trastàmara la progressiva pèrdua d'autonomia política per part del municipi estarà condicionada pel ritme i la gravetat dels conflictes interns en el si de l'elit urbana. És a dir, no per una imposició de directrius 
polítiques pròpies prefixades per part de la Corona. Al cap i la fi, l'intervencionisme regi Trastàmara en les eleccions no va ser resultat d'un programa polític planificat per la monarquia, ni en particular d'Alfons el Magnànim, sinó que va esdevindre com a continuació d'un procés de transformació de les relacions entre la Corona i l'elit dirigent que, almenys, es començaria a documentar puntualment en temps de Martí l'Humà, tot i que ja comptava amb els seus precedents en temps de Pere Cerimoniós. En el marc d'aquest procés, la singularitat de la ingerència règia en ciutat de Xàtiva abans de la introducció de la insaculació és que permet observar les primeres petjades de les noves relacions de poder entre el rei i les elits dirigents municipals del regne de València.

Fecha de recepción: 9 de marzo de 2017

Fecha de aceptación: 20 de junio de 2017 
